\title{
Reflections on the Important Role of Ideological Education in College Students' Innovation and Entrepreneurship
}

\author{
Liu Peng \\ Shenyang Jianzhu University. No.9, Hunnan East Road, Hunnan New District, Shenyang \\ City,Liaoning, P.R.China \\ 56901090@qq.com
}

Keywords: Innovation and entrepreneurship; Ideological education; College students

\begin{abstract}
The policy of "mass entrepreneurship and innovation" promoted in China makes the innovation and entrepreneurship education of colleges and universities particularly important. Because ideological and political education permeates all aspects of college education, it is closely related to innovation and entrepreneurship education. With the deepening of the reform of the social market system, the continuous expansion of colleges and universities, the employment problem of college students has become one of the focuses of the society. In the face of the new economic normal, the state actively encourages college students to start their own businesses, which provides a new impetus for China's economic development. It is worth noting that solving the problem of college students' employment is that college students' entrepreneurship not only requires certain financial support, but also the mental preparation in entrepreneurship is also a very important factor. Employment and entrepreneurship education has also become an important part of higher education, and ideological education has important guiding significance in college students whether they are employed or entrepreneurial. This paper analyzes the role and current problems of ideological education in the development of college students' entrepreneurship, and guides college students to recognize the importance of ideological education.
\end{abstract}

\section{Introduction}

Employment is the foundation of people's livelihood. Facing the severe employment situation of college students today, establishing a new concept of college students' entrepreneurial education, changing the employment thinking mode, strengthening the cultivation of university entrepreneurial awareness, and changing passive employment into active entrepreneurship is the main way to solve the employment problem of college students. It is also an effective measure to ease the pressure on social employment. At present, China's socialist market economic system has been generally established. In such an environment, in order to carry out self-employment, we must face the increasingly complex market environment. Only by preparing enough mentally and maintaining the correctness of the thinking in the market environment can college students better carry out the road of entrepreneurship. College students must have correct entrepreneurial ideas and entrepreneurial ideas, and the school's ideological and political education guidance is an indispensable content. At present, many colleges and universities have carried out employment and entrepreneurship guidance courses for the employment of college students, including both the guidance education of employment ideas and the guiding education of entrepreneurial ideas. No matter what kind of education, it plays an important role in the future development of college students.

\section{The Role of Ideological Education in Innovation and Entrepreneurship Education}

Ensure the political direction of innovation and entrepreneurship education talents, innovation and entrepreneurship education, and ultimately to cultivate talents. The result of talent cultivation is not only related to the growth of an individual's life, but also to the destiny of the country and the nation. Therefore, the process of innovation and entrepreneurship education in colleges and universities must firmly grasp the political direction and train students to become builders and successors of the socialist cause. Under the new situation of social transformation in contemporary 
China, profound changes have taken place in various fields such as economy, politics, ideology and culture, the combination of tradition and modernity, the integration and collision of Chinese and Western cultures, the re-adjustment of interests, the rapid expansion of information, the rapid development of network life, etc., these changes have a strong impact on people's psychology, people's values show a diversified development trend. In addition, various social problems have emerged in an endless stream, which has impacted people's thinking. The pattern of Marxism's dominant position in the faith has been gradually broken. Under such a social background, college students will inevitably have problems such as confusion of political beliefs, lack of ideals and beliefs, confusion of value orientation, etc., which will certainly affect the development of society and the stability of the country. In the process of ideological education in colleges and universities, it is to uphold the guiding ideology of Marxism, arm the students' minds with the theoretical system of socialism with Chinese characteristics, help students correctly understand the situation at home and abroad, and solve the students' ideological confusion. College students firmly believe in the road of socialism with Chinese characteristics, confidence in theory, confidence in the system, dare to face various difficulties and risks in the path of socialism with Chinese characteristics, and can devote themselves to their own study and life in a more energetic state. Go and grow themselves into talents that are useful to the country and society. Therefore, in the process of innovation and entrepreneurship education, we must attach great importance to ideological education and ensure the political direction of talent cultivation.

Help to improve the ideological and moral quality of innovative entrepreneurial talents. Innovative and entrepreneurial education in colleges and universities cannot simply focus on innovation and entrepreneurship practice and employment education. It is not only based on the number of entrepreneurial entities and the success of entrepreneurial projects as its criterion. Instead, in the process of innovation and entrepreneurship education, it is necessary to cultivate college students' awareness of innovation and entrepreneurship, knowledge and ability, and pay more attention to the cultivation of students' ideological and moral qualities. In the process of developing a socialist market economy, we inevitably suffer some negative effects. The nature of the market economy's profit-seeking, the various erroneous trends of thought at home and abroad, the concept of decay, and the current lack of perfection of the socialist ethics system, China's ideological and moral field is facing unprecedented challenges. As an important part of the social group, college students' ideological and moral issues have become increasingly prominent. Some college students advocate wrong ideas such as money worship, hedonism, and extreme individualism. Some college students lack integrity, lack of morality, and so on.

\section{The Problems Existing in Ideological Education in College Students' Innovation and Entrepreneurship}

Economic globalization has also made social resource sharing more convenient. China's entrepreneurship education started relatively late, and the theoretical system combining ideological education and entrepreneurship education is imperfect. The research on the two is also in its infancy.

Research on the theory of ideological education is not enough. Ideological education is a quality education in the field of ideology. At present, many colleges and universities often focus on practicality when carrying out entrepreneurship education, while ignoring the role and influence of ideological education in entrepreneurship education. Make college students have a useless and unnecessary understanding of ideological education. In addition, because the teachers in colleges and universities are not professional teachers, their own limitations and theoretical research are not deep, and in the face of the questions raised by students, the attitude of avoiding choices also hinders the formation of new ideological education research and methods.

Ignore the practicality of ideological education in entrepreneurship education. Ideological education is not only theoretically not valued in entrepreneurship education, but also neglected its role in practice. The weak theoretical research foundation makes the practical guidance function 
insufficient, and the combination of theory and practice is not close enough. Because ideological education does not combine the actual situation, colleges and universities have not developed a set of programs that meet the needs of real college students to cultivate their professional skills and professional qualities, so the effect of ideological education in entrepreneurship is not obvious and easy to be ignored.

The emphasis on ideological education in entrepreneurship education is not enough. If the ideological education is out of the actual needs, it is like a useless paper book. With the deepening of reform and opening up, the global economy informatization and economic value interests gradually take advantage. For college students who have just left the school, factors such as the blindness of cognition of the social market and the uncertainty of personal goals are often difficult to restrain the influence of individualism and moneyism, and put themselves on an incorrect track. In the process of college students' entrepreneurship, they need not only entrepreneurial ability, but also the spirit, concept, values, professional ethics of entrepreneurship, but these ideas have not received full attention in entrepreneurship. In addition, due to traditional ideas, many parents oppose their children to start a business, fear that their children will take risks and fail to start a business. They think that it is better to find a stable and stable job. In the collision of these two ideas, entrepreneurship education is recognized to a low degree, and ideological education is more neglected and diluted, which is not conducive to the spiritual cultivation of college students' entrepreneurship.

Lack of a unified education system. China's education is mainly for exam-oriented education, which makes college students lack the awareness and exercise of self-employment. Many students mainly study textbooks to cope with exams, which leads to the lack of independent entrepreneurship. Ideological education is of positive significance to college students' entrepreneurship. However, the relevant systems and work teams of ideological education in entrepreneurship education have not yet been fully implemented. In particular, educational mechanisms such as assessment management have not yet formed. That is to say, there is no unified system of ideological education and entrepreneurship, nor does it provide a good entrepreneurial environment for college students or carry out related simulation entrepreneurial activities, which have caused certain obstacles to the implementation of ideological education in college students' entrepreneurship.

\section{The influence of ideological education on college students' innovation and entrepreneurship}

Awareness of their own conditions. The guidance of ideological education has an important influence on the entrepreneurship of college students. First of all, it is manifested in the influence of the understanding of their own conditions. College students' self-employment is a difficult process, and the lack of understanding of their own conditions will inevitably lead to the failure of entrepreneurship. The guiding work of ideological education can guide students to understand their own characteristics from the level of thought. Through the analysis of thoughts, students can deeply understand the important role of their own conditions in self-employment, and thus can strengthen the construction of their own entrepreneurial conditions. Through the guidance of ideological and political education, students can clearly understand the advantages and disadvantages of starting a business in the market environment, so that they can do their own scientific positioning and prepare their own conditions for entrepreneurship.

Understanding of the market environment. The ideological and political education guiding work is not only aimed at the students themselves in their own entrepreneurship, the college students are the driving force of entrepreneurship, and the market environment is the driving force to drive the force. If the understanding of the market environment is not thorough, it is difficult for students to grasp the changes in the market and start a successful business. In the guidance of ideological education, the teaching teachers who are instructing should carry out ideological and political education in strict accordance with the law of market changes, so that they can establish a correct market concept and have the ability to analyze the market and detect the market. In other words, in the guidance of college students' entrepreneurial education, it is necessary to highlight the 
importance of the market environment for entrepreneurship, so that students can establish a correct market concept and be able to grasp the market dynamics to start a business.

Awareness of the entrepreneurial process. The road to entrepreneurship has never been smooth, especially for college students. Due to the lack of social experience and relevant work experience, the understanding of the market environment is not very familiar, and the entrepreneurial process can be described as difficult. In the guidance of ideological and political education, college ideological and political education workers should strengthen the ideological guidance of the entrepreneurial process, so that students can establish a confident entrepreneurial concept. In the guidance, the teacher should focus on the students' complexity and difficulty in the entrepreneurial process, so that students have a scientific understanding and understanding of the entrepreneurial process, which prepares students for future entrepreneurial work and solve problems in actual entrepreneurial work. Both have important significance. In short, ideological education guidance directly affects students' understanding and understanding of the entrepreneurial process.

\section{Summary}

In short, as a situation in which college students face difficulties in employment, they should not put too much psychological pressure on themselves, but should appropriately change the concept of employment. Entrepreneurship is also a high-level career choice. The education work of colleges and universities not only pays attention to the achievements of college students in school, but also the influence of ideological education on college students' learning. Integrating ideological education into college students' entrepreneurship can better cultivate healthy mind and body talents, cultivate correct entrepreneurial awareness and career choices for college students, enhance social responsibility, and contribute their own strength to society. Under the support of popular innovation and entrepreneurial policies, college students' self-employment has become an important thrust for China's economic development, relying on the courage of the newborn calf not afraid of the tiger. Some students have succeeded in entrepreneurship and have created a world of success. However, as an ideological and political education worker in colleges and universities, it is still necessary to pay attention to the risks and experience of college students in the process of entrepreneurship. Therefore, strengthening the ideological and political education guidance in the process of college students' innovation and entrepreneurship should become an important task for the ideological and political education workers in the future stage.

\section{References}

[1]Xu S. Discussion on the Role of Ideological and Political Education in College Students' Innovation and Entrepreneurship[J]. Journal of Hubei Correspondence University, 2017.

[2]Yang Z Y. The Ideological and Political Education Research Based on Innovation and Entrepreneurship for College Students[J]. Journal of Hubei Correspondence University, 2017.

[3]Min-Yang W U. The Role of Ideological and Political Education in the Innovation and Entrepreneurship of University Students[J]. Education Teaching Forum, 2018.

[4]Jing Y, Peng Y A. Research of the Political and Ideological Education in Innovation and Entrepreneurship Eduation for College Students[J]. Value Engineering, 2016.

[5]Li K, Wei K. The Research on the Ideological and Political Education of College Students in the University Entrepreneurship Education[J]. Journal of Chengdu University of Traditional Chinese Medicine, 2015.

[6]Peng X. On the Guiding Role of Ideological and Political Education in College Students' Independent Entrepreneurship[J]. Science Education Article Collects, 2012.

[7]Lin H E, Marxism S O, University Y N. The Analysis of the Role of Ideological and Political Theory Course in Innovation and Entrepreneurship Education[J]. Journal of Xichang College, 2017.

[8]Lei Z M, Department F L, University G M. Ideological and Political Education,Innovation and Entrepreneurship Education and Employment Guidance in Higher Colleges[J]. Journal of Hubei 
Correspondence University, 2018.

[9]Zhan P, Wang H J. Discussion on the Innovation of College Students' Ideological and Political Education Based on Entrepreneurship Education Idea[J]. Journal of Jilin Teachers Institute of Engineering \& Technology, 2014.

[10]Dai G, Humanities S O, University Y M. Ideological Education in the Employment and Entrepreneurship of Minority College Students[J]. Journal of Chuxiong Normal University, 2017.

[11]Jing L X, Kong F B. Research on the Ways of Fusion of Innovation and Entrepreneurship Education and Ideological and Political Education[J]. Education Teaching Forum, 2018.

[12]Wang T, Fan Y, Wang Y, et al. Research on the Innovation of the Ideological and Political Education in Colleges and Universities based on Entrepreneurship Education[J]. Journal of Huainan Vocational \& Technical College, 2017.

[13]Li L D, Bi A, University L. The ideological and political education's innovative guiding role in the process of college students' employment and entrepreneurship[J]. Journal of Jiamusi Vocational Institute, 2017.

[14]Fan Y C. Entrepreneurship of College Students' Ideological and Political Education from the Education Innovation Research[J]. Journal of Hubei Correspondence University, 2017. 